\title{
First preparation and isolation of a stable ferrocenylketene
}

\author{
Nanyan Fu, Annette D. Allen, and Thomas T. Tidwell* \\ Department of Chemistry, University of Toronto, Toronto, Ontario M5S 3H6 Canada \\ Email: ttidwell@chem.utoronto.ca \\ Dedicated to Professor Ernst Anders on the occasion of his $65^{\text {th }}$ birthday, and in \\ recognition of his early pioneering work on stereoselectivity in ketene reactions
}

\begin{abstract}
Ferrocenyl(triisopropylsilyl)ketene (6) is formed upon photolysis of the diazo ketone 5, and is the first example of an isolated ferrocenylketene. The X-ray structure of $\mathbf{6}$ shows that the ketenyl moiety is protected from both sides, by the ferrocenyl group and by the triisopropylsilyl group, respectively. The ketene is remarkably unreactive towards nucleophiles, and is less reactive towards $2 \mathrm{mM} \mathrm{n-BuNH}{ }_{2}$ than the parent ferrocenylketene by a factor of $7 \times 10^{8}$, a result attributed to steric shielding to attack of the nucleophile, and the ketene stabilizing effect of the silyl substituent.
\end{abstract}

Keywords: Ferrocene, ketenes, steric protection, amination

\section{Introduction}

Ketenes have been studied for more than 100 years, and have attracted increasing interest in recent years. ${ }^{1}$ However the study of ferrocenylketenes have until recently received little attention, and these species had only been generated as unobserved reactive intermediates. ${ }^{2} \mathrm{We}$ undertook investigations of this family, and by DFT computations found ferrocenylketene (1) to be destabilized by $1.6 \mathrm{kcal} / \mathrm{mol}$ relative to phenylketene, as determined by isodesmic comparison to the corresponding alkenes (Scheme 1). ${ }^{3}$

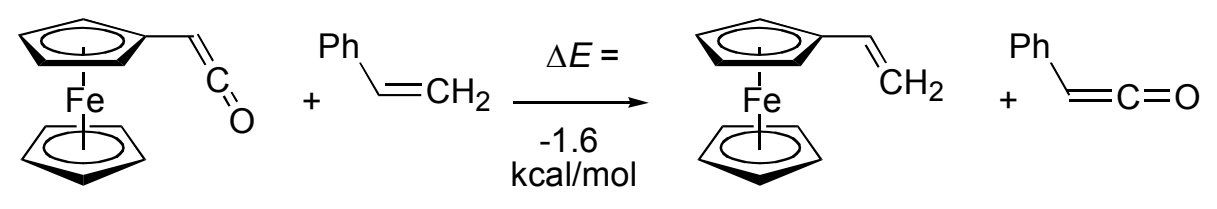

\section{Scheme 1}


Ferrocenylketene 1 was generated by Wolff rearrangement in $\mathrm{CH}_{3} \mathrm{CN}$ and was directly observed by UV and IR spectroscopy as a short-lived and reactive intermediate in solution. ${ }^{3}$ Ferrocenylketene was identified by the characteristic IR band at $2119 \mathrm{~cm}^{-1}$, and was found to have a rate constant for reaction with $n-\mathrm{BuNH}_{2}$ forming the corresponding amide less than that for phenylketene by a factor of 5 (Scheme 2). ${ }^{3}$ 1,2-Bisferrocenyl-1,2-bisketene 4 was also prepared as a transient intermediate by photochemical ring opening of the corresponding cyclobutenedione $\mathbf{3}$, and $\mathbf{4}$ underwent rapid ring closure back to the cyclobutenedione with a rate constant 67 times greater than that for the corresponding 1,2-diphenyl-1,2-bisketene (Scheme 2). ${ }^{3}$ Thus the computational and experimental results indicated that ferrocenylketenes are less stabilized and more reactive than phenylketenes. This is consistent with the known destabilizing effects of electron donating substituents on ketenes, ${ }^{1 \mathrm{~d}}$ and the strong electron donating ability of the ferrocenyl group. ${ }^{3}$

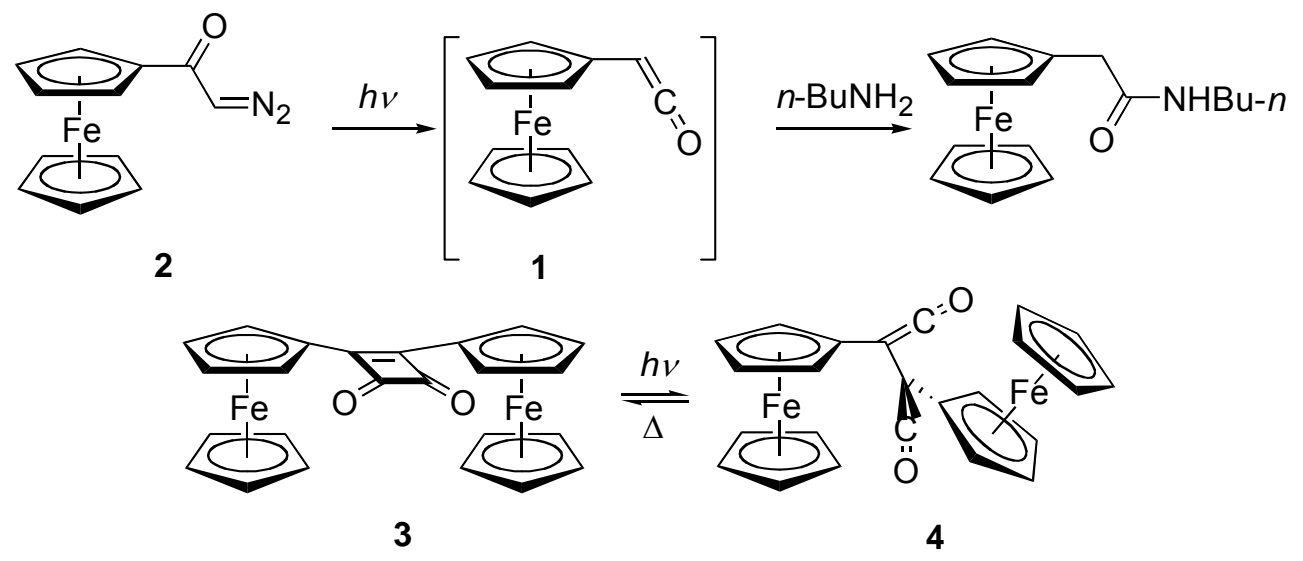

\section{Scheme 2}

These investigations revealed ferrocenylketenes to be short-lived and highly reactive intermediates, and because of the interesting structural properties of ferrocenylketene we have made an effort to prepare a long-lived and isolable example of this elusive family. Because of the known stabilizing effect of silyl groups on ketenes, and the demonstrated use of bulky trialkylsilyl groups for this purpose, ${ }^{1 \mathrm{~d}, \mathrm{f}, 4}$ we have taken this approach, and now report the successful conclusion of this search.

\section{Results and Discussion}

Reaction of diazoacetylferrocene (2) with triisopropylsilyl triflate gave triisopropylsilyldiazoacetylferrocene (5) in 40\% yield, which upon photolysis gave ferrocenyl(triisopropylsilyl)ketene (6) as a stable orange solid in 68\% isolated yield (Scheme 3). The X-ray structure of $\mathbf{6}$ was determined (Figure 1), and revealed a structure with the ketenyl 
group blocked on each side, by the ferrocenyl and triisopropylsilyl groups, respectively. It is notable that the ferrocenyl group rotates so that it effectively shields the ketenyl group, with dihedral angles $\mathrm{C} 5-\mathrm{C} 1-\mathrm{C} 11-\mathrm{C} 12$ of $-73.8^{\circ}$ and $\mathrm{C} 2-\mathrm{C} 1-\mathrm{C} 11-\mathrm{C} 12$ of $113.5^{\circ}$. In the parent ferrocenylketene 1 the ketenyl group is calculated by DFT methods to be rotated away from the iron, with a dihedral angle between the cyclopentadienyl ring and the ketenyl group of $10.7^{\circ}$. $^{3}$

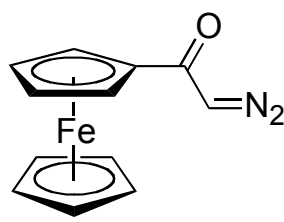

2

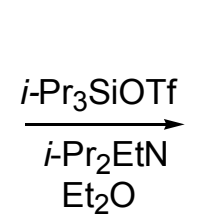

5

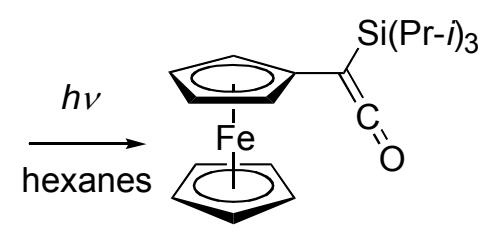

6

\section{Scheme 3}

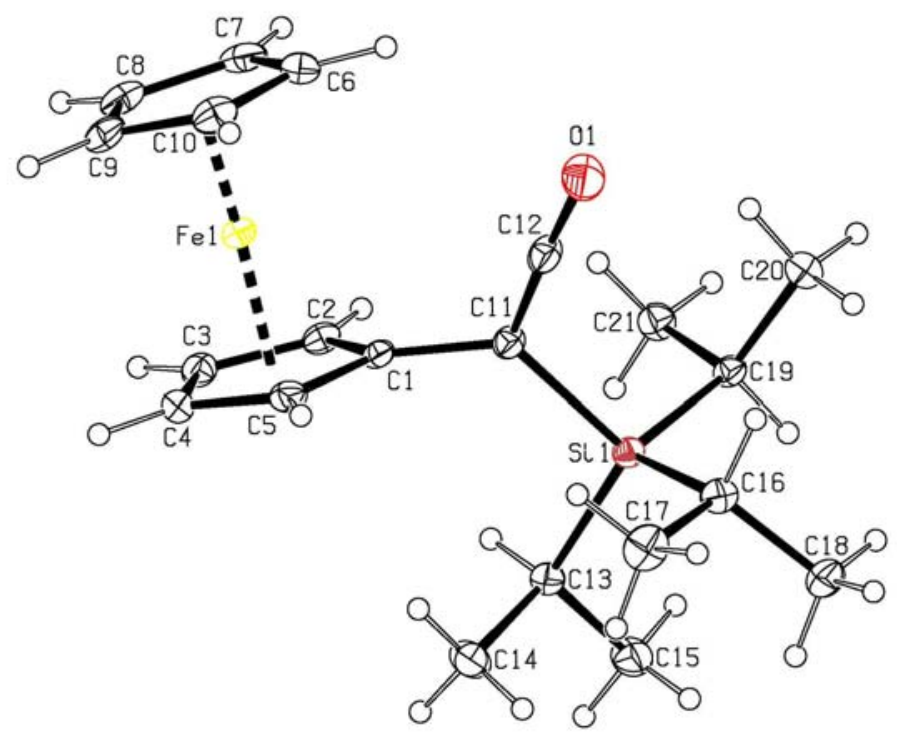

Figure 1. X-ray structure of ferrocenyl(triisopropylsilyl)ketene 6.

Evidence for the steric crowding in $\mathbf{6}$ is found in the compressed bond angles C1-C11$\mathrm{C} 12$ between the ferrocenyl and ketenyl goups of $118.9^{\circ}$, and the angle C12-C11-Sil between the ketenyl and TIPS groups of $116.4^{\circ}$, and the expanded angle C1-C11-Si1 between the ferrocenyl and TIPS groups of $124.6^{\circ}$ (Supporting Information). The ketenyl group is slightly bent away from the ferrocenyl group, with an angle $\mathrm{C} 11-\mathrm{C} 12-\mathrm{O} 1$ of $176.6^{\circ}$, and a speculation may be made 
that this is due to an electronic interaction between the iron and the carbonyl carbon C12. However, further study would be necessary to elucidate such an interaction.

To obtain quantitative reactivity data for $\mathbf{6}$ we have chosen to examine its stability towards nucleophiles, as there are many studies of the reactivity of ketenes towards water ${ }^{1 \mathrm{~d}, 6}$ and amines. ${ }^{6,7}$ The reaction of 6 with $n-\mathrm{BuNH}_{2}$ was examined, and this formed the amide 7 (Scheme 4) as a rather unstable but isolable crystalline solid, which was identified by its spectroscopic properties, including the expected non-equivalence of the diastereotopic protons and carbons. The kinetics of reaction were measured using both UV detection for the decrease in absorbance at $232 \mathrm{~nm}$ and by IR detection for the decrease in the ketenyl absorbance at $2086 \mathrm{~cm}^{-1}$ and for the increase of the amide absorbance at $1658 \mathrm{~cm}^{-1}$. The measured rate constants are given in Table 1, and were fit according to Scheme 5 by Equation 1 with a higher order dependence on [ $n$ $\mathrm{BuNH}_{2}$, as shown in Figure 1. This analysis has been used for other relatively unreactive ketenes, and interpreted as showing assistance by further amine molecules for amine addition to the ketene. ${ }^{7 \mathrm{c}-\mathrm{f}}$ Direct comparison of the measured rate constants with $2 \mathrm{mM} n-\mathrm{BuNH}_{2}$ for the triisopropylsilyl substituted ferrocenylketene $\mathbf{6}$ and the parent ferrocenylketene $\mathbf{1}^{8}$ shows the former to be less reactive by a factor of $7 \times 10^{8}$, and this enormous rate difference confirms the strong steric protection afforded by the substituents in $\mathbf{6}$. Twisting of the ketenyl group out of conjugation with the ferrocenyl group also destabilizes the transition state for amine addition.

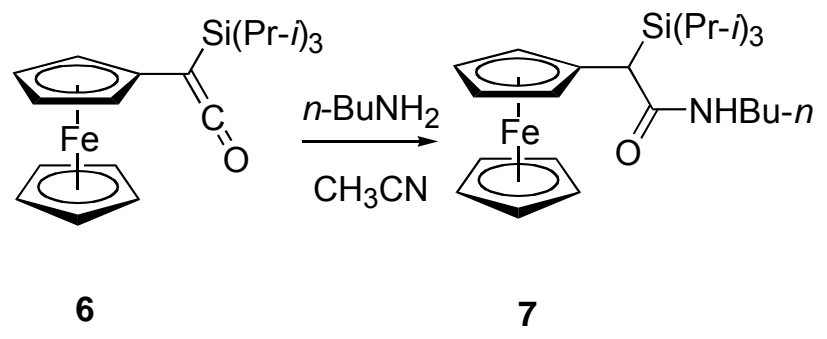

\section{Scheme 4}

Table 1. Rate constants for reaction of ketene 6 with $n-\mathrm{BuNH}_{2}$ in $\mathrm{CH}_{3} \mathrm{CN}$ at $25{ }^{\circ} \mathrm{C}$

\begin{tabular}{|l|l|l|l|l|l|}
\hline$\left[n-\mathrm{BuNH}_{2}\right] \mathrm{M}$ & Method & $k_{\text {obs }}\left(\mathrm{s}^{-1}\right)$ & {$\left[n-\mathrm{BuNH}_{2}\right] \mathrm{M}$} & Method & $k_{\mathrm{obs}}\left(\mathrm{s}^{-1}\right)$ \\
\hline $0.207 \times 10^{-2}$ & $\mathrm{UV}^{a}$ & $(3.54 \pm 0.24) \times 10^{-4}$ & $1.03 \times 10^{-2}$ & $\mathrm{UV}^{a}$ & $(7.83 \pm 0.28) \times 10^{-3}$ \\
\hline $0.517 \times 10^{-2}$ & $\mathrm{UV}^{a}$ & $(2.08 \pm 0.02) \times 10^{-3}$ & $3.10 \times 10^{-2}$ & $\mathrm{UV}^{a}$ & $(6.79 \pm 0.80) \times 10^{-2}$ \\
\hline $0.517 \times 10^{-2}$ & $\mathrm{IR}^{b}$ & $(1.85 \pm 0.07) \times 10^{-3}$ & $5.17 \times 10^{-2}$ & $\mathrm{UV}^{a}$ & $(1.46 \pm 0.07) \times 10^{-1}$ \\
\hline $0.517 \times 10^{-2}$ & $\mathrm{IR}^{c}$ & $(2.37 \pm 0.05) \times 10^{-3}$ & & & \\
\hline
\end{tabular}

${ }^{a}$ Measured at $232 \mathrm{~nm} .{ }^{b}$ Measured at $2086 \mathrm{~cm}^{-1}$. ${ }^{c}$ Measured at $1658 \mathrm{~cm}^{-1}$. 


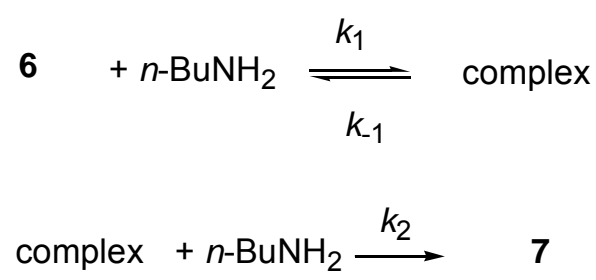

\section{Scheme 5}

$$
\left.k_{\mathrm{obs}}=\left(k_{2} / k_{-1}\right) k_{1}\left[n-\mathrm{BuNH}_{2}\right]^{2}\right) /\left(k_{2} / k_{-1}\left[n-\mathrm{BuNH}_{2}\right]+1\right)
$$

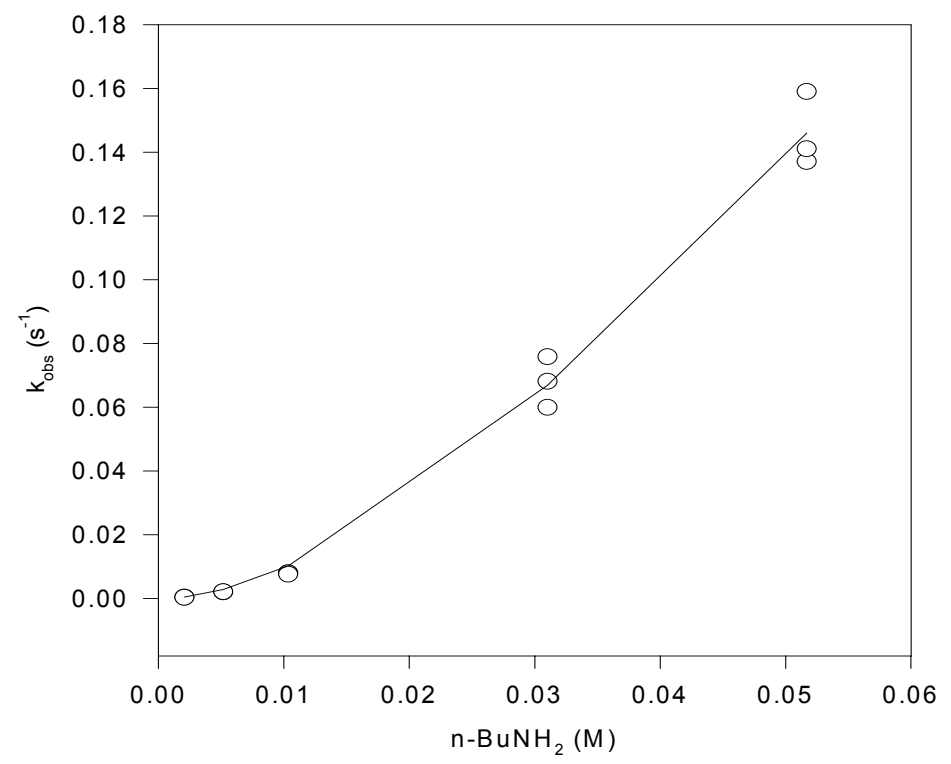

Figure 1. Fit of observed rate constants versus $\left[n-\mathrm{BuNH}_{2}\right]$ for amination of $\mathbf{6}$.

In conclusion, $\mathbf{6}$ is the first ferrocenylketene to be isolated and subjected to structure determination. This ketene shows remarkable stability towards amination, and the unreactivity of $\mathbf{6}$ in amination compared to the parent $\mathbf{1}$ may be attributed to steric protection of the ketenyl moiety, which is shielded on both sides from the approach of other reagents, and to reduced conjugative stabilization in the transition state for amine addition, together with stabilization of the ketene by the silyl substituent.

\section{Experimental Section}

General Procedures. Chromatography was carried out using silica gel with the solvents indicated. ${ }^{1} \mathrm{H}$ and ${ }^{13} \mathrm{C}$ NMR spectra were recorded on Varian Gemini, Mercury, or Unity spectrometers. Infrared spectra were obtained using a Varian FTS7000 instrument. 
2-Diazo-1-ferrocenyl-2-triisopropylsilylethanone (5). A solution of triisopropylsilyl trifluoromethanesulfonate $(270 \mathrm{uL}, 1 \mathrm{mmol})$ in ether $(5 \mathrm{~mL})$ was added dropwise to a solution of 2-diazo-1-ferrocenylethanone (254 mg, $1 \mathrm{mmol}$ ) and diisopropylethylamine (174 uL, $1 \mathrm{mmol})$ in ether $(25 \mathrm{~mL})$ at $0{ }^{\circ} \mathrm{C}$ with stirring. The mixture was allowed to warm to room temperature and was stirred overnight. The solution was filtered and the collected solid was washed with ether. The reddish orange clear filtrate was concentrated to give red oil. Chromatography (silica gel, $\mathrm{CH}_{2} \mathrm{Cl}_{2}$ : hexanes 1: $2 \mathrm{v} / \mathrm{v}, 1 \% \mathrm{Et}_{3} \mathrm{~N}$ ) gave 2-diazo-1-ferrocenyl-2-triisopropylsilylethanone (5) as orange crystals $(173 \mathrm{mg}, 40 \%)$, mp 76-78 ${ }^{\circ} \mathrm{C} .{ }^{1} \mathrm{H} \mathrm{NMR}\left(400 \mathrm{MHz}, \mathrm{CDCl}_{3}\right) \delta 4.79$ (t, J=2.0 Hz, $2 \mathrm{H}), 4.43(\mathrm{t}, J=2.0 \mathrm{~Hz}, 2 \mathrm{H}), 4.26(\mathrm{~s}, 5 \mathrm{H}), 1.43-1.40(\mathrm{~m}, 3 \mathrm{H}), 1.16(\mathrm{~d}, J=7.5 \mathrm{~Hz}, 18 \mathrm{H}) .{ }^{13} \mathrm{C}$ NMR $\left(100 \mathrm{MHz}, \mathrm{CDCl}_{3}\right) \delta 193.0,81.6,71.1,70.0,69.4,50.3,18.8,11.8$. IR $\left(\mathrm{CDCl}_{3}\right) 2064 \mathrm{~cm}^{-1}$. $\mathrm{UV} / \mathrm{Vis}$ (hexanes) $\lambda_{\max }(\varepsilon) 265 \mathrm{~nm}\left(7.37 \times 10^{3}, \mathrm{sh}\right), 341 \mathrm{~nm}\left(1.20 \times 10^{3}\right), 450 \mathrm{~nm}\left(3.91 \times 10^{2}\right)$. EIMS

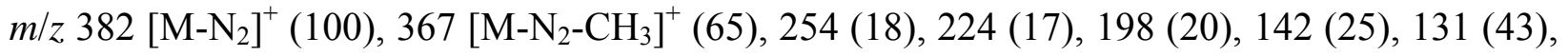
121 (79), 103 (45), 84 (39), 75 (71), 56 (47). HREIMS m/z calcd for $\mathrm{C}_{21} \mathrm{H}_{30} \mathrm{FeOSi}\left(\left[\mathrm{M}-\mathrm{N}_{2}\right]^{+}\right.$) 382.1415 , found 382.1426 .

Ferrocenyl(triisopropylsilyl)ketene (6). 2-Diazo-1-ferrocenyl-2-triisopropylsilyl-ethanone (163 $\mathrm{mg}, 0.397 \mathrm{mmol})$ was dissolved in hexanes $(50 \mathrm{~mL})$ and degassed by bubbling in nitrogen for 20 $\min$ at $5{ }^{\circ} \mathrm{C}$. The solution was irradiated $1 \mathrm{~h}$ using $300 \mathrm{~nm}$ lamps at $5{ }^{\circ} \mathrm{C}$, and concentrated to give an orange oil. Chromatography (silica gel, $\mathrm{CH}_{2} \mathrm{Cl}_{2}$ : hexanes 1: $5 \mathrm{v} / \mathrm{v}$ ) gave 6 as an orange oil which solidified when kept in the refrigerator as orange crystals (103 mg, 68\%), mp 49.5-50.5 ${ }^{\circ} \mathrm{C} .{ }^{1} \mathrm{H}$ NMR $\left(400 \mathrm{MHz}, \mathrm{CDCl}_{3}\right) \delta 4.20(\mathrm{~s}, 5 \mathrm{H}), 4.12(\mathrm{t}, J=1.8 \mathrm{~Hz}, 2 \mathrm{H}), 4.08(\mathrm{t}, J=1.8 \mathrm{~Hz}, 2 \mathrm{H})$, 1.15-1.09 (m, 3H), $\left.1.06(\mathrm{~d}, J=5.9 \mathrm{~Hz}, 18 \mathrm{H}) .{ }^{13} \mathrm{C} \mathrm{NMR} \mathrm{(100} \mathrm{MHz,} \mathrm{CDCl}_{3}\right) \delta 180.4,75.3,70.3$, 68.9, 67.2, 18.4, 12.6, 12.0. IR $\left(\mathrm{CDCl}_{3}\right) 2085 \mathrm{~cm}^{-1}$. UV/Vis $\left(\mathrm{CDCl}_{3}\right) \lambda_{\max }(\varepsilon) 443 \mathrm{~nm}(127)$; $\mathrm{UV} / \mathrm{Vis}\left(\mathrm{CH}_{3} \mathrm{CN}\right) \lambda_{\max }(\varepsilon) 445 \mathrm{~nm}(112)$; UV/Vis (isooctane) $\lambda_{\max }(\varepsilon) 445 \mathrm{~nm}(112) . \mathrm{EIMS} \mathrm{m} / \mathrm{z}$ $382 \mathrm{M}^{+}$(100), 252 (23). HREIMS m/z calcd for $\mathrm{C}_{21} \mathrm{H}_{30}$ FeOSi 382.1415, found 382.1413.

$\boldsymbol{N}$-n-Butyl ferrocenyl(triisopropylsilyl)acetamide (7). $n$-Butylamine (100 uL, $74 \mathrm{mg}, 1 \mathrm{mmol}$ ) was added dropwise to a solution of ferrocenyl(triisopropylsilyl)ketene $(5.5 \mathrm{mg}, 0.014 \mathrm{mmol})$ in pentane $(5 \mathrm{~mL})$ under nitrogen. The mixture was stirred $15 \mathrm{~min}$ at room temperature, and the resulting clear yellow solution was concentrated to give an orange oil. Chromatography (silica gel, $\left.\mathrm{CH}_{2} \mathrm{Cl}_{2}\right)$ gave 7 as orange crystals $(6.2 \mathrm{mg}, 94 \%)$, mp 96-97 ${ }^{\circ} \mathrm{C} .{ }^{1} \mathrm{H} \mathrm{NMR}\left(400 \mathrm{MHz}, \mathrm{CDCl}_{3}\right)$ $\delta 5.76(\mathrm{~s}$, br, $1 \mathrm{H}), 4.60-4.59(\mathrm{~m}, 1 \mathrm{H}), 4.10(\mathrm{~s}, 5 \mathrm{H}), 4.10-4.08(\mathrm{~m}, 1 \mathrm{H}), 4.05-4.03(\mathrm{~m}, 1 \mathrm{H}), 3.98-$ $3.97(\mathrm{~m}, 1 \mathrm{H}), 3.40-3.28(\mathrm{~m}, 2 \mathrm{H}), 2.93(\mathrm{~s}, 1 \mathrm{H}), 1.63-1.57(\mathrm{~m}, 2 \mathrm{H}), 1.46-1.40(\mathrm{~m}, 2 \mathrm{H}), 1.14-1.05$ $(\mathrm{m}, 3 \mathrm{H}), 1.02-0.99(\mathrm{~m}, 18 \mathrm{H}), 0.97(\mathrm{t}, J=7.3 \mathrm{~Hz}, 3 \mathrm{H}) .{ }^{13} \mathrm{C} \mathrm{NMR}\left(100 \mathrm{MHz}, \mathrm{CDCl}_{3}\right) \delta 172.5$, 69.0, 68.6, 67.6, 66.4, 39.8, 37.1, 32.0, 20.7, 19.1, 19.0, 14.0, 11.6. IR (KBr) 3360, 3096, 2945, $2867,1636,1517,1512,1457,1384,1313,1231,1168,1106 \mathrm{~cm}^{-1}$. ESIMS m/z $455 \mathrm{M}^{+}, 412$ [M$\left.\mathrm{C}_{3} \mathrm{H}_{7}\right]^{+}$. HRESIMS $\mathrm{m} / \mathrm{z}$ calcd for $\mathrm{C}_{25} \mathrm{H}_{41} \mathrm{FeNOSi} 455.2301$, found 455.2324.

\section{UV kinetic measurements}

For the amination of 6 a stock solution of $5.17 \times 10^{-2} \mathrm{M} n-\mathrm{BuNH}_{2}$ in $\mathrm{CH}_{3} \mathrm{CN}$ was prepared by weighing $n$ - $\mathrm{BuNH}_{2}$ and diluting with $\mathrm{CH}_{3} \mathrm{CN}$. Aliquots $(10 \mu \mathrm{L})$ of $7.4 \times 10^{-3} \mathrm{M} 6$ in $\mathrm{CH}_{3} \mathrm{CN}$ were injected into $n-\mathrm{BuNH}_{2}$ in $\mathrm{CH}_{3} \mathrm{CN}(1.2 \mathrm{~mL})$ in a $1 \mathrm{~cm} \mathrm{UV}$-cell at $25{ }^{\circ} \mathrm{C}$. At $232 \mathrm{~nm}$ first 
order decay with time was monitored and evaluated using the program Igor Pro. The kinetic data were fit by equation 2 , where $a=\left(k_{2} / k_{-1}\right) k_{1}$ and $b=\left(k_{2} / k_{-1}\right)$

$$
k_{\mathrm{obs}}=a\left[n-\mathrm{BuNH}_{2}\right]^{2} /\left(b\left[n-\mathrm{BuNH}_{2}\right]+1\right)
$$

$\begin{array}{lllll}\text { Parameter } & \text { Value } & \text { StdErr } & \text { CV }(\%) & \text { Dependencies } \\ a & 1.1750 \mathrm{e}+2 & 2.5630 \mathrm{e}+1 & 2.1820 \mathrm{e}+1 & 9.8960 \mathrm{e}-1 \\ b & 2.2240 \mathrm{e}+1 & 9.4400 \mathrm{e}+0 & 4.2440 \mathrm{e}+1 & 9.8960 \mathrm{e}-1\end{array}$

\section{IR kinetic measurements}

Ketene $6\left(10 \mu \mathrm{L}\right.$ of $7.4 \times 10^{-3} \mathrm{M}$ solution in $\left.\mathrm{CH}_{3} \mathrm{CN}\right)$ was injected into $5.17 \times 10^{-3} \mathrm{M} \mathrm{n}-\mathrm{BuNH}_{2}$ solution in $\mathrm{CH}_{3} \mathrm{CN}(500 \mu \mathrm{L})$, and the resulting solution was rapidly transferred into a $1 \mathrm{~mm} \mathrm{CaF}_{2}$ IR cell. The initial scan served as the background scan, and a good first order decay was measured at $2086 \mathrm{~cm}^{-1}$, while at $1658 \mathrm{~cm}^{-1}$ a concomitant growth attributed to formation of the amide 7 was measured, with fair first order behavior.

\section{Supplementary information}

X-ray CIF and RTF files

\section{Acknowledgements}

Financial support by the Natural Sciences and Engineering Research Council of Canada is gratefully acknowledged.

\section{References and Notes}

1. (a) Staudinger, H. Chem. Ber. 1905, 38, 1735. (b) Staudinger, H. Chem. Ber. 1906, 39, 3062. (c) Staudinger, H. Chem. Ber. 1911, 44, 533. (d) Tidwell, T. T. Ketenes, Wiley: NY, $2^{\text {nd }}$ Edn., 2006. (e) Tidwell, T. T. Eur. J. Org. Chem. 2006, 563. (f) Tidwell, T. T. Angew. Chem. Int. Ed. 2005, 44, 5778.

2. (a) Lindsey, C. M.; Ferguson, J. M. Abstracts of Papers, 231st ACS National Meeting, Atlanta, GA, March 26-30, 2006. (b) Bonini, B. F.; Femoni, C.; Comes-Franchini, M.; Fochi, M.; Mazzanti, G.; Ricci, A.; Varchi, G. Synlett 2001, 1092. (c) Hisatome, M.; Watanabe, J.; Yamashita, R.; Yoshida, S.; Yamakawa, K. Bull. Chem. Soc. Jpn. 1994, 67, 490. 
3. Aguilar-Aguilar, A.; Allen, A. D.; Peña-Cabrera, E.; Fedorov, A.; Fu, N.; Henry-Riyad, H.; Kobayashi, S.; Leuninger, J.; Schmid, U.; Tidwell, T. T.; Verma, R. J. Org. Chem. 2005, 71, 9556.

4. (a) George, M.; Danheiser, R. L. Science of Synthesis (Houben-Weyl), Vol. 23, Chap 2. Bellus, D.; Danheiser, R., Eds., Thieme Verlag: Stuttgart, 2006. (b) Pommier, A.; Kocienski, P.; Pons, J. -M. J. Chem. Soc., Perkin Trans. 1 1998, 2105. (c) Brückmann, R.; Schneider, K.; Maas, G. Tetrahedron 1989, 45,5517.

5. Regitz, M.; Menz, F. Chem. Ber. 1968, 101, 2622.

6. (a) Allen, A.D.; Tidwell, T.T. J. Am. Chem. Soc. 1987, 109, 2774. (b) Allen, A. D.; Fedorov, A. V.; Najafian, K.; Tidwell, T. T.; Vukovic, S. J. Am. Chem. Soc. 2004, 126, 15777. (c) Chiang, Y.; Fedorov, A. V.; Kresge, A. J.; Onyido, I.; Tidwell, T. T. J. Am. Chem. Soc. 2004, 126, 9382.

7. (a) Wagner, B. D.; Arnold, B. R.; Brown, G. S.; Lusztyk, J. J. Am. Chem. Soc. 1998, 120, 1827. (b) Sung, K.; Tidwell, T. T. J. Am. Chem. Soc. 1998, 120, 3043. (c) Raspoet, G.; Nguyen, M. T.; Kelly, S.; Hegarty, A. F. J. Org. Chem. 1998, 63, 9669. (d) Allen, A. D.; Tidwell, T. T. J. Org. Chem. 1999, 64, 266. (e) Allen, A.D.; Moore, P. A.; Missiha, S.; Tidwell, T. T. J. Org. Chem. 1999, 64, 4690. (f) De Lucas, N. C.; Netto-Ferreira, J. C.; Andraos, J.; Scaiano, J. C. J. Org. Chem. 2001, 66, 5016.

8. Measured rate constants for $1\left(10^{5} \mathrm{~s}^{-1}\right)$ at $25{ }^{\circ} \mathrm{C}$ with $\left[n-\mathrm{BuNH}_{2}\right](\mathrm{mM})$ were $4.24(4.0)$, $2.53(2.0), 1.16(1.0), 0.778(0.75), 0.536(0.50)$, and $0.233(0.25)$, ref 3 . 